\title{
AMELANCHIER MEDIK. (ROSACEAE) FRUITS - A NUTRITION DIETARY PRODUCT AND A SOURCE MATERIAL FOR PHYTOPHARMACOLOGY
}

\author{
Kuklina Alla ${ }^{1 *}$, Sorokopudov Vladimir ${ }^{2}$, Stepanova Anna ${ }^{3}$ \\ ${ }^{1}$ Main Botanical Garden named after N.V. Tsitsin Russian Academy of Sciences, Moscow, Russia \\ ${ }^{2}$ All-Russian Horticultural Institute for Breeding, Agrotechnology and Nursery, Moscow, Russia \\ ${ }^{3}$ Belgorod National Research University, Belgorod, Russia
}

Received 25.6. 2017

Revised 28. 6. 2017

Published 27. 11. 2017

Fruits of Amelanchier spicata (Lam.) K.Koch, Amelanchier alnifolia (Nutt.) Nutt.), Amelanchier florida Lindl., Amelanchier canadensis (L.) Medik. and Amelanchier laevis Wieg. (Rosaceae) are rich in ascorbic acid (up to $30.3 \mathrm{mg} \%$ ), total sugar (up to $8.7 \%$ ), they are also saturated with bioflavonoids, among which there are anthocyanins (353.1-608.2 mg\%), possessing antioxidant qualities. Amelanchier fruits are the nutritious dietary product, in which the content of acids and sugars is balanced. They are suitable for various types of processing and can serve as phytopharmacological raw materials. Biochemical analysis of leaves of Amelanchier spicata and Amelanchier alnifolia showed that they are enriched with bioflavonoids (260-370 mg\%), which is also valuable for phytopharmacology. Amelanchier alnifolia and closely related Amelanchier florida have especially large and delicious fruits, more enriched with saccharides and anthocyanins. They have prospects for a further selection as a highly productive garden and food culture. Amelanchier laevis plants luxuriantly bloom, but they differ in an irregular fruit bearing and smaller fruits $(0.6 \mathrm{~g}$ in weight), they are promising as an ornamental culture.

Keywords: adventisation; naturalization; invasive activity; anthropogenic transformation

\section{Introduction}

Species of the genus Amelanchier Medik. (Maloideae, Rosaceae) are used as a decorative and a fruit culture. The nutritional qualities and chemical composition of the fruit are better studied in Saskatoon (Amelanchier alnifolia (Nutt.) Nutt.) - native to the North American plains. Its dark-purple, berry-like pome fruit range in diameter from 10 to $15 \mathrm{~mm}$ in average. Fruits are sweet, contain up to 14-19\% of sugar and consist of fructose and glucose. The amount of pectins is $0.25-0.95 \mathrm{mg}$ per a gram of wet weight. The malic dominates among the organic acids (0.63\%). Fruit pH ranged 3.65-4.18. The fruits of Saskatoon are full of biologically active substances - thiamine (30 $\mathrm{mkg} \%$ ), riboflavin (12 mkg\%), carotenoids (about $0.3 \mathrm{mg} \%$ ) and ascorbic acid (8-61 mg\%). Among bioflavonoids $(0.5-1.6 \%)$ there are catechins (70-163 mg\%), flavonols (30-160 mg\%). Among the oxycinnamic acids there are chlorogenic (up $291 \mathrm{mg} \%$ ), para-coumaric (30-69 mg\%) and caffeic acids (7-22 mg\%) with hepatoprotective activity (Стрельцина, Бурмистров, 2006). The bright coloration of juice of the Saskatoon fruit is due to the presence of anthocyanin (414-852 mg\%), analysis identified cyanidin3-galactoside, cyanidin-3-glucoside (Mazza, 1986; Ozga et al., 2006), and cyanidin-3-arabinoside (Чулков и др., 2011) and delphinidine (Писарев и др., 2011).

*Corresponding author: Alla Kuklina, Main Botanical Garden named after N.V. Tsitsin Russian Academy of Sciences, Moscow, Russia, $\bowtie$ alla_gbsad@mail.ru 
In the fruits of Saskatoon there are $67.5 \mathrm{mg}$ of manganese, $67.0 \mathrm{mg}$ of iron, $31.8 \mathrm{mg}$ of sodium, $7.2 \mathrm{mg}$ of copper, $16.5 \mathrm{mg}$ of zinc, $34.8 \mathrm{mg}$ of barium, $0.38 \mathrm{mg}$ of molybdenum and aluminum $74.5 \mathrm{mg} / 100 \mathrm{~g}$ wet weight, as well as $0.44 \%$ calcium, $0.16 \%$ phosphorous, $1.2 \%$ potasse, $0.2 \%$ magnese, $0.06 \%$ sulfur, 9.7\% protein and 19\% of fiber (Mazza, 1982; Zatylny et al., 2005).

In Russian Botanical Gardens, Amelanchier spicata (Lam.) K.Koch, Amelanchier alnifolia, which got naturalized in forests and became invasive plants, are often cultivated (Kuklina, 2011). The fruits of Amelanchier spicata weigh $0.27-0.38 \mathrm{~g}$, they are on a short panicle of 4-10 pieces; Amelanchier alnifolia fruits are larger, weigh $0.41-0.65 \mathrm{~g}$, on a panicle of 10-15 pieces. They are purple-black with a bluish bloom. They are appreciated for their flavouring qualities, are used in food and in folk medicine. Fruits are useful for health promotion, especially for diseases of liver, kidneys, stomach and heart. Fresh, dried and air-dried fruits have astringent properties, they help with digestive disorders (Сорокопудов и др., 2011; Виноградова и Куклина, 2012).

There are also Amelanchier florida Lindl., Amelanchier canadensis (L.) Medik. and Amelanchier laevis Wieg planted in Russia. Juice, jam, confiture, jelly are made from the Amelanchier fruits; brightly colored drinks are made with citric acid - stewed fruit and wine (Якушина и Куклина,"1994; Куклина, 2007).

The goal of this work includes a study of the weight and a biochemical composition of fruits in the 5 Amelanchier species cultivated in Central Russia, in connection with a possibility of its use for nutrition and phytopharmacology.

\section{Materials and methodology}

The 5 species was used as the material: Amelanchier spicata, Amelanchier alnifolia, Amelanchier florida, Amelanchier canadensis and Amelanchier laevis, cultivated in the Main Botanical Garden named after N.V. Tsitsin, Russian Academy of Sciences (Moscow) and in the Botanical Garden of Belgorod, National Research University (Belgorod). The biochemical analysis was carried out in the period 2010-2016 on fresh fruits harvested during the full ripeness phase. Every year we analyzed samples from 10 shrubs belonging to 5 species of Amelanchier. Dry soluble substances and the amount of sugars were measured by using an optical refractometer IRF-454-Б 2M (Russia); Ascorbic acid - by tilting the extracts with Tilmans paint with the help of the spectrophotometer CF-102 (Russia), anthocyanins - by the spectrophotometric method. The amount of bioflavonoids was determined by the chromatographic method, the content of organic acids by titration method according to the "State Pharmacopoeia USSR, XI" (www.fito.nnov.ru/pharmacopaea) on dry fruits. The results were processed in Microsoft Excel. The permissible error did not exceed the norm ( $P \leq 5 \%)$.

\section{Results and discussion}

The 5 species of Amelanchier under analysis, showed a good winter-hardiness in the conditions of Central Russia, and an annual abundant flowering. An inflorescence of Amelanchier spicata, $6 \mathrm{~cm}$ long, contains up to 11 fruits weighing about $1 \mathrm{~g}$; an inflorescence of Amelanchier alnifolia, $6 \mathrm{~cm}$ in length, contains up to 9 fruits weighing 0.6-1.1 g; that of Amelanchier florida $5 \mathrm{~cm}$ long contains up to 11 fruits weighing $0.79-0.99 \mathrm{~g}$; that of Amelanchier canadensis $6 \mathrm{~cm}$ long contains up to 12 fruits 0.6-0.98 $\mathrm{g}$ in weight, and that of Amelanchier laevis $4.5 \mathrm{~cm}$ long contains up to 8 fruits, which are formed not annually, with their weight of $0.52-0.78 \mathrm{~g}$.

According to our data, dry fruits Amelanchier spicata and Amelanchier alnifolia have total bioflavonoids (quercetin, vitexin, 4-rhamnozide vitexin, hyperoside) - 180-410 mg\%. Among the 
bioflavonoids in the Amelanchier fruits the leading place is occupied by anthocyanins with up to 2150 mg\% per dry weight (Куклина и др., 2017), or up to $840 \mathrm{mg}$ per wet weight (Стельцина и Бурмистров, 2006), thanks to which the juice has a bright crimson color. On this basis Amelanchier fruits, saturated with biologically active in combination with trace elements, have a therapeutic value and can serve as a source material for phytopharmacology.

As it is shown in Table 1, the fruits of the five species of Amelanchier contain up to $40 \mathrm{mg} \%$ of ascorbic acid and $30.3 \%$ of soluble solids. The juice of ripe fruit has a sum of anthocyanin (353-608 mg\%).

Table 1 The chemical composition of Amelanchier spp. fruits from Belgorod, in 2010-2015

\begin{tabular}{|l|c|c|c|}
\hline Species & Soluble solids, ${ }^{, \%}$ & Ascorbic acid, $\mathbf{~ m g \%}$ & Total anthocyanin content, $\mathbf{~ m g \%}$ \\
\hline A. spicata & $30.3 \pm 1.3$ & $40.2 \pm 1.6$ & $408.4 \pm 20.8$ \\
\hline A. alnifolia & $30.1 \pm 1.5$ & $43.8 \pm 1.1$ & $482.8 \pm 12.6$ \\
\hline A. florida & $27.3 \pm 1.0$ & $40.3 \pm 1.7$ & $608.2 \pm 15.9$ \\
\hline A. canadensis & $29.2 \pm 1.0$ & $42.8 \pm 1.7$ & $458.7 \pm 29.7$ \\
\hline A. laevis & $23.9 \pm 1.1$ & $41.2 \pm 1.2$ & $353.1 \pm 24.1$ \\
\hline
\end{tabular}

The taste and dietary properties of fruits depend on the ratio of sugars and organic acids. The amount of sugars, among of which monosaccharides prevail, in the fruits of Amelanchier changed insignificantly (within 7.3-8.8\%, CV = 1-3\%), despite the annual fluctuations in weather conditions and the dry summer of 2010 (Table 2).

Table 2 Total sugar of Amelanchier spp. fruits from Belgorod (\%), in 2010-2013

\begin{tabular}{|l|c|c|c|c|c|}
\hline Species & $\mathbf{2 0 1 0}$ & $\mathbf{2 0 1 1}$ & $\mathbf{2 0 1 2}$ & $\mathbf{2 0 1 3}$ & $\mathbf{M} \pm \mathbf{m}, \mathbf{\%}$ \\
\hline A. spicata & $7.9 \pm 0.3$ & $7.3 \pm 0.5$ & $7.5 \pm 0.9$ & $7.6 \pm 1.1$ & $7.6 \pm 0.2$ \\
\hline A. alnifolia & $7.5 \pm 1.1$ & $8.3 \pm 0.2$ & $8.3 \pm 0.6$ & $8.6 \pm 0.6$ & $8.4 \pm 0.1$ \\
\hline A. florida & $8.8 \pm 0.2$ & $8.5 \pm 0.4$ & $8.3 \pm 0.8$ & $8.6 \pm 0.9$ & $8.7 \pm 0.2$ \\
\hline A. canadensis & $8.1 \pm 0.2$ & $8.3 \pm 0.5$ & $8.0 \pm 0.8$ & $8.1 \pm 1.0$ & $8.1 \pm 0.1$ \\
\hline A. laevis & $8.8 \pm 0.4$ & $8.4 \pm 0.6$ & $8.2 \pm 0.9$ & $8.1 \pm 1.1$ & $8.4 \pm 0.3$ \\
\hline
\end{tabular}

The sweetest fruits were noted in Amelanchier florida (8.7\%), as well as in Amelanchier alnifolia and Amelanchier laevis (8.4\%). Less sugar was found in fruits of A. spicata (7.6\%). In 2015-2016 we established, that dried fruits of $A$. spicata were almost 1.5 times more saturated with organic acids (0.75-0.99\%), than those of A. alnifolia (0.49-0.64\%).

The study revealed high positive correlations between the content of dry soluble substances and sugars $(r=0.999)$, which is a reliable criterion for the selection of highly productive cultivars. After harvesting Amelanchier fruits can be stored at room temperature for 2-3 days, and at temperature of 0-10 ${ }^{\circ} \mathrm{C}$ - up to 7 days, and the juice yield amounts to 70\% (Степанова, 2015).

It is known that in folk medicine decoctions of leaves are used to rinse the mouth with purulent inflammation, stomatitis and help with gastrointestinal diseases. Biochemical analysis of Amelanchier spicata and Amelanchier alnifolia samples showed that not only fruits but also leaves 
are enriched with bioflavonoids (260-370 mg\%), which are also valuable for phytopharmacology (Куклина и др., 2017).

\section{Conclusions}

In Amelanchier spicata, Amelanchier alnifolia, Amelanchier florida, Amelanchier canadensis and Amelanchier laevis, the panicle is from 4.8 to $7.3 \mathrm{~cm}$ in length. Mature fruits further differ in the balanced content of sugars (up to $8.8 \%$ ) and organic acids (up to $0.99 \%$ ), therefore they are a nutritious and dietary product important in the human diet. The presence of ascorbic acid (more than $40 \mathrm{mg} \%$ ) and bioflavonoids, among which anthocyanins prevails (up to $608 \mathrm{mg} \%$ ), makes the fruit necessary to improve immunity against viral and oncodiseases, useful in cardiovascular disorders. Amelanchier fruits are a valuable source material for phytopharmacology.

The studied plant species are unequal in their nutritional advantages and adaptive possibilities in natural biocenoses. Especially large and delicious fruits, more enriched with saccharides and anthocyanins, have Amelanchier alnifolia and closely related Amelanchier florida, which have prospects for a further selection as a highly productive garden and food culture. Amelanchier laevis plants in Russia are rather luxuriantly blooming and elegant, but they differ in an irregular fruit bearing and smaller fruits ( $0.6 \mathrm{~g}$ in weight), they are promising as an ornamental culture, like species of Amelanchier canadensis, suitable for the landscape gardening.

The spread of Amelanchier spicata in culture should be limited, as far as its highly adapted individuals are capable of active growing due to their long hypogeogenic rhizomes and spreading seeds, and pose a serious threat to the native flora (Kuklina, 2011); and their fruits, although they can be used as a medical source materials, are characterized by weaker flavouring qualities.

\section{Acknowledgments}

The authors thank Natalia Tsybulko, PhD of pharmaceutical, for help in the biochemical research. The work was supported by the RFBR, 15-29-02556.

\section{References}

Kuklina, A.G. 2011. Naturalization of Amelanchier Species from North America in a Secondary Habitat. Russian Journal of Biological Invasions, vol. 2, № 2-3, p. 103-107. DOI:10.1134/S2075111711020056

Mazza, G. 1982. Chemical Composition of Saskatoon Berries Amelanchier alnifolia Nutt. J."Food Sci., vol. 47, no. 5, p. 1730-1731. DOI: 10.1111/j.1365-2621.1982.tb05022.x

Mazza G. 1986. Anthocyanins and other phenolics of saskatoon berries Amelanchier alnifolia Nutt. J. Food Sci., vol. 51, p. 1260-1264. DOI: 10.1111/j.1365-2621.1986.tb13100.x

Ozga, J.A., Saeed, A., Reinecke, D.M. 2006. Anthocyanins and nutrient components of Saskatoon fruits (Amelanchier alnifolia Nutt.). Can. J. Plant Sci., vol. 86, no. 1, p. 193-197. https://doi.org/10.4141/P05-139.

Zatylny, A.M., Ziehl, W.D., St-Pierre, R.G. 2005. Physicochemical properties of fruit of 16 saskatoon (Amelanchier alnifolia Nutt.) cultivars. Can. J. Plant Sci., vol. 85, no. 4, p. 933-938. https://doi.org/10.4141/ P04-065

Виноградова, Ю.К., Куклина, А.Г. 2012. Ресурсный потенциал инвазионных видов растений. Возможности использования чужеродных растений. Москва: ГЕОС. 186 с. ISBN 978-5-8991 18-556-2.

Куклина, А.Г. 2007. Жимолость, ирга. Москва: «Ниола-Пресс». 204 с. ISBN 978-5-366-00138-0.

Куклина, А.Г., Сорокопудов, В.Н., Цыбулько, Н.С. 2017. Фитохимический анализ плодов и листьев ирги (Amelanchier Medik.) в культигенных и инвазионных популяциях. Плодоводство и ягодоводство России. т. 49, с. 39-42. 
Писарев, Д.И., Новиков, О.О., Писарева, Н.А., Автина, Н.В., Безменова, М.Д., Степанова, А.В. 2011. Изучение состава антоцианов ирги ольхолистной Amelanchier alnifolia Nutt. с использованием матрично-активированной лазерной десорбционной ионизации (MALDI). Научные ведомости Белгородского университета. Серия Медицина. Фармация, вып. 16/2, № 22 (117). с. 167-172.

Сорокопудов, В.Н., Мячикова, Н.И., Степанова, А.В. 2011. Плоды редких культур Ботанического сада Белгородского государственного университета как основа диетического питания и сырья для фармацевтической промышленности. Научные Ведомости Белгородского университета. Серия Медичина. Фармачия, вып. 13/2, № 4 (99), с. 199-203.

Степанова, А.В. 2015. Эколого-биологическая оценка генофонда ирги (Amelanchier Medik.) при интродукции в условиях юго-запада ЦЧР: автореферат диссертации. Рамонь. 24 с.

Стрельцина, С.А., Бурмистров, Л.А. 2006. Биохимический состав ирги ольхолистной (Amelanchier alnifolia) в условиях северо-запада Российской Федерации. Аграрная Россия, № 6, с. 63-67.

Чулков, А.Н., Дейнека, В.И., Сорокопудов, В.Н., Дейнека, Л.А., Степанова, А.В. 2011. Антоцианы плодов шести видов Amelanchier sp. Научные ведомости Белгородского государственного университета. Серия «Естественные науки», вып. 15/2, № 9 (104), с. 208-214.

Якушина Э.И., Куклина А.Г. 1994. Кустарники с чудесными плодами. Москва: Московский рабочий. 204 c. ISBN 5-239-01433-7 